MACIEJ EDER

Instytut Języka Polskiego

Polskiej Akademii Nauk w Krakowie

\title{
ZAGADKOWE „ŹWIERZE O JEDNYM OKU”, CZYLI O FRASZCE III 78 KOCHANOWSKIEGO
}

\begin{abstract}
Słowa kluczowe: Jan Kochanowski, fraszki, Gadka, obscena, skatologia
\end{abstract}
Keywords: Jan Kochanowski, trifles, Gadka, Riddle, obscenity, scatology

1.

Tematem niniejszego szkicu jest epigram Jana Kochanowskiego wydrukowany w trzeciej księdze Fraszek (Fr III 78). Utwór ten zatytułowany jest Gadka, a więc 'zagadka', i mimo oczywistej z pozoru treści doczekał się wielu sprzecznych prób wyjaśnienia jego warstwy metaforycznej. Moim celem nie jest pokazanie, że poprzednie interpretacje są nietrafione - trudno przecież falsyfikować odczytania oparte na spekulacjach - lecz wypracowanie spójnej propozycji lekturowej, która scalałaby dotychczasowe intuicje badaczy i była zarazem dostatecznie mocno osadzona w kontekstach dawnej literatury i kultury. Interpretacja zaproponowana poniżej odwołuje się zresztą, tak jak i wszystkie poprzednie, przede wszystkim do domysłów: w sytuacji, w której sam tekst nie daje jednoznacznego klucza do rozszyfrowania użytej w nim metaforyki, procedurę hermeneutyczną trzeba oprzeć na dalszych lub bliższych (ale w gruncie rzeczy i tak zawsze niepewnych) paralelach pozatekstowych.

Nieustające zainteresowanie „gadką” Kochanowskiego w literaturze przedmiotu zapewne jest niewspółmierne do roli owej fraszki (w gruncie rzeczy marginalnej) w obrębie całego zbioru, a tym bardziej do miejsca Fr III 78 w kontekście całej twórczości czarnoleskiego poety. $\mathrm{Z}$ drugiej jednak strony problemy interpretacyjne narosłe wokół tego konkretnego epigramu pokazują pewien ogólny problem Fraszek, z którym mierzyli się już Jan Januszowski (m.in. wykluczając cały zbiór pt. Fraszki z wydania zbiorowego dzieł Kochanowskiego z roku 1585) czy Bohomolec (przez zabiegi cenzorskie dokonane na własnym wydaniu Fraszek z roku 1767) ${ }^{1}$.

${ }^{1}$ Paulina Buchwald-Pelcowa, „Dzieje wydań tekstu Fraszek Jana Kochanowskiego od XVI do XVIII wieku”, in Historia literatury i historia książki. Studia nad książka i literatura od średniowiecza po wiek XVIII (Kraków: Universitas, 2005), 145-148. 
Problem ten wyartykułował Januszowski w przedmowie do wydania zbiorowego pt. Jan Kochanowski: otóż niektóre fraszki, zdaniem wydawcy, „,są barzo potrzebne, a drugie podobno barzo bezpieczne" („bezpieczne” w znaczeniu etymologicznym, czyli 'pozostawione bez opieki, nieprzypilnowane'). Wysiłki interpretacyjne podjęte w niniejszym przyczynku wyrastają zatem z przekonania, że rozwikłanie owego jednego małego wycinka skomplikowanej konstrukcji, jaką niewątpliwie są Fraszki, rzuci nowe światło na zbiór Kochanowskiego również w innych jego miejscach. Zacznijmy od przytoczenia omawianej fraszki w całości:

Gadká

Jest źwiérzę o jednym oku,

Któré záwżdy stoi w kroku.

Ślepym bełtem w nie strzéláją

Á ná oko ugadzáją.

Głos jego by piorunowy,

Á zalot niepráwie zdrowy³.

Najmniej kontrowersji wzbudzały dwa ostatnie wersy. Jak wprost wynika $\mathrm{z}$ tekstu, wspomniane na początku „źwierzę o jednym oku” ma wydawać śmierdzący zapach i głośny odgłos, w czym można upatrywać pośledniej części ciała ludzkiego i jej fizjologicznych przypadłości. Jeśli jednak zgodzimy się z tezą, że w końcowych wersach rzeczywiście chodzi o zadek, to pojawia się oczywisty kłopot $\mathrm{z}$ właściwym odczytaniem początku fraszki. Z jednej strony „Źwierzę o jednym oku" daje się łatwo powiązać z fizjologicznymi efektami opisanymi w końcówce (wtedy „źwierzę” oznaczałoby oczywiście odbyt), z drugiej jednak strony któż miałby „ugadzać na oko”, a więc strzelać do zadka, i w jakim celu miałby to czynić? Jeśli z kolei pójść innym ciągiem skojarzeń i „ugadzanie” umieszczonego w rozkroku „oka” utożsamiać z aktem płciowym, to wtedy kłopotliwe stają się dwa ostanie wersy - spółkowanie trudno przecież pogodzić ze smrodem i ,piorunowym głosem”.

Próby rozwiązania zagadki podjął się Krzyżanowski. W opisie dostrzegł lufę muszkietu opieranego na widłach lub armaty osadzonej na lawecie, tylko z pozoru wyglądającą jak śmierdzący odbyt. Jak twierdzi wydawca, „dowcip zagadki polega na jej dwuznacznym rozwiązaniu: na pierwszy rzut oka chodzi tu o zadek, naprawdę o broń palną" ${ }^{4}$. Janusz Pelc w swoim komentarzu, odnosząc się

${ }^{2}$ Jan Kochanowski, Dzieła wszystkie. Wprowadzenie wydawnicze do edycji, ed. Maria Renata Mayenowa et Jerzy Woronczak, vol. intr. (Wrocław: Ossolineum, 1983), 166.

${ }^{3}$ Transkrypcja wszystkich fragmentów Fraszek za powstającym wydaniem, które ukaże się jako III tom Dziet wszystkich Jana Kochanowskiego (tzw. wydanie sejmowe). Transkrypcja oparta jest na unikatowym egzemplarzu pierwodruku Fraszek z 1584, przechowywanym dziś w Bibliotece Państwowej (Staatsbibliothek) w Berlinie pod sygn. 3 in Libri impr.rar.qu. 297. Vide Jan Kochanowski, Fraszki (Kraków: Jan Januszowski, 1584), 129-130.

${ }^{4}$ Jan Kochanowski, Dzieła polskie, ed. Julian Krzyżanowski, vol. 1 (Warszawa: PIW, 1952), 198. 
do propozycji Krzyżanowskiego, dodaje: ,już raczej to drugie!”5. Marian Pankowski idzie nieco innym tropem, pisząc o Fr III 78: „nie brak nawet portretu ciała homoseksualisty, ujętego w ramki przejrzystej zagadki”" ${ }^{6}$ co wspomniany powyżej Pelc kwituje: „sens [...] dość oczywisty”7. Piotr Oczko i Tomasz Nastulczyk odnieśli się do tej hipotezy w monografii Homoseksualność staropolska, wzmiankę o Fr III 78 umieszczając w podrozdziale Nieporozumienia i nadinterpretacje z lakonicznym komentarzem, że tekst jest „pozbawiony całkowicie wszelkich aluzji homoerotycznych" ". Wypada oczywiście żałować, że nie poznaliśmy argumentacji autorów: być może tropy interpretacyjne podjęte w studium niniejszym są już od dawna przetarte.

Joanna Duska proponuje rozwiązanie radykalne, a mianowicie zupełnie rezygnuje z erotyki na rzecz rozumienia skatologicznego: „źwierzę o jednym oku” to przenośny ustęp, deska $\mathrm{z}$ wyciętym otworem oparta na czterech drewnianych nogach ${ }^{9}$, „Ugadzanie na oko” daje się wtedy wyjaśnić jako defekowanie; zapach i odgłosy z wersów 5-6 też pasują do całego obrazu. Takie rozwiązanie zagadki jest błyskotliwe i na pierwszy rzut oka przekonujące, ale zebrany materiał językowy wydaje się zbyt wątly, by na „klozetowym” rozumieniu fraszki poprzestać.

Mówiąc w pewnym skrócie, zagadkę Kochanowskiego szturmowano więc z dwóch głównych kierunków: skatologicznego i obscenicznego, przy milczącym założeniu, że jedna interpretacja $\mathrm{z}$ definicji wyklucza drugą. W pewnym skrócie można by rzec, że dotychczasowi interpretatorzy na ludzkie ciało spoglądają albo od przodu (sensu obsceno), albo od tyłu (sensu scatologico), nie dopuszczając do myśli - w czym zapewne przeszkadza dobra znajomość ludzkiej anatomii - że kultura popularna nie zawsze dba o precyzyjnie rozgraniczenie obu sfer cielesnych. Jedynym tedy logicznym połączeniem obu sprzecznych perspektyw wydawała się hipoteza homoseksualna. W niniejszym studium podjęta zostanie próba pokazania, że w obu aspektach ludzkiej cielesności nie ma zasadniczej sprzeczności czy rozłączności, tak jak nie ma jej w staropolskiej skatologii i obscenach, umieszczanych nierzadko w bezpośredniej bliskości.

Zacznijmy od przywołania kilku bezspornych faktów. Przypuszczenie, że w dwóch ostatnich wersach Fr III 78 pojawia się kontekst skatologiczny - pasujący może bardziej do twórczości Reja niż Kochanowskiego - daje się w prosty sposób obronić przez przywołanie dwóch innych fraszek, w których explicite

${ }^{5}$ Jan Kochanowski, Fraszki, ed. Janusz Pelc, BN, I 163 (Wrocław: Ossolineum, 1991), 155.

${ }^{6}$ Marian Pankowski, „Polska poezja nieokrzesana (próba określenia zjawiska)”, Teksty, no. 4 (1978): 45.

${ }^{7}$ Jan Kochanowski, Fraszki, 1991, 155.

${ }^{8}$ Tomasz Nastulczyk et Piotr Oczko, Homoseksualność staropolska (Kraków: Collegium Columbinum, 2012), 389.

${ }^{9}$ Joanna Duska, „Tajemnicza Gadka z księgi II Fraszek Jana Kochanowskiego. Rozwiązanie zagadki", in Wiazanie sobótkowe. Studia o Janie Kochanowskim, ed. Estera Lasocińska et Wiesław Pawlak (Warszawa: IBL PAN, 2015), 348-355. 
mowa o wydalaniu: jest to po pierwsze Fr I 90 Na ucztę, po drugie zaś Fr III 70 O koźle.

Bez cienia wątpliwości można też twierdzić, że w zbiorze występują obscena, i to w natężeniu o wiele większym, niż sądził pierwszy cenzor (i zarazem pierwszy wydawca) Fraszek, Jan Januszowski, na co zresztą już dawno zwracał uwagę Krzyżanowski ${ }^{10}$. Można tu znaleźć zarówno treści jawnie obsceniczne (Fr I 55, I 59, I 60, I 61, II 82, III 85, III 86), jak i odnoszące się do sfery erotycznej za pomocą dość oczywistych aluzji (Fr I 34, I 74, III 82), wreszcie takie, w których warstwa seksualna jest czytelna dla wyrobionego odbiorcy, znającego łacińskie czy greckie wzory (modelowym przykładem jest Fr I 26, manifest poetycki Kochanowskiego pozbawiony zupełnie treści frywolnych, ale jednoznacznie odwołujący się do najbardziej chyba wulgarnego wiersza łacińskiej starożytności, tzn. do Pieśni XVI Katullusa). Znajdziemy we Fraszkach słownictwo oznaczające wprost genitalia: „macierzyzna” (I 34), „mądzie” (I 59, II 41), ,jajca” (II 41, III 56), „jądra” (II 82) albo aluzyjne, ale zarazem ujednoznacznione przez kontekst sytuacyjny: „grosz”, „cis” (III 86), „żyła”, „bindasz” (I 55), „krzoska” (III 86), „wanna” (III 41). Pojawiają się wreszcie wyrażenia dwuznaczne, które w warstwie słów nie niosą treści frywolnych, ale dają oczywiste powody do takich skojarzeń - takim przykładem jest „wiosło” z Fr III 86: żądny zysku właściciel gospody dostrzega, „że mu do żony z wiosłem flis przymierzać raczy” (III 86) ${ }^{11}$.

Nie będzie zatem nadużyciem, jeśli w ,gadce” przedstawionej przez Fr III 78 będziemy się dopatrywali sensów nieprzystojnych. Hipotezę tę znacząco wzmacnia fakt, że co najmniej dwie inne zagadki ukryte we Fraszkach również dotyczą obcowania cielesnego. Pierwsza z nich to Fr I 37 Na Barbarę. Kluczem do rozwiązania zagadki w każdym kolejnym dystychu jest rym, który naprowadza czytelnika na spodziewane słowo:

Jákoś mi już skaczesz słábo,

Folguj sobie, miła Bárbáro, proszę cię.

Najistotniejszy dla niniejszego wywodu jest jednak nie tyle incipit (i spodziewane „babo” w drugim wersie), ile wersy $7-8$ fraszki:

Ále ty wżdy nie bądź głupia,

Nieznájomym nie daj dudkowáć przed sobą.

Wprawdzie nie jest do końca jasne, czy w oczekiwanym „nie daj dupia” należy się doszukiwać biernika l.poj. od leksemu „dupa”, czy może raczej od rzeczownika

${ }^{10}$ Julian Krzyżanowski, W wieku Reja i Stańczyka. Szkice z dziejów odrodzenia w Polsce (Warszawa: PWN, 1958), 52.

${ }^{11}$ Joanna Birczyńska, „Słownik erotyczny «Fraszek» Jana Kochanowskiego”, in Jan Kochanowski i epoka renesansu. W 450 rocznicę urodzin poety (1530-1980), ed. Teresa Michałowska (Warszawa: PWN, 1984), 334-348. 
„dup” ('dziupla'), nie ulega jednak wątpliwości, że sens zdania jest jednoznaczny i zupełnie zrozumiały.

Drugą zagadkę łatwo przeoczyć przy pobieżnej lekturze Fraszek, kryje się bowiem w jednej krótkiej frazie, a w zasadzie w jednym słowie ${ }^{12}$. Samo jednak rozwiązanie nie powinno nastręczyć większych trudności. Oto Fr I $60 \mathrm{Na}$ miernika, przywołana w całości:

\section{Ná mierniká}

Kiedyście się tych pomiarów ták dobrze uczyli,

Że wiécie, ilékroć koło obróci się w mili,

Zgádniciéż mi, wiele rázów, niż jeden raz minie,

Mádgálená pod namiotem żywym duszą kinie.

Fraszkę Na miernika należy rozpatrywać w zasadzie wyłącznie w kontekście Fr I 53 Na matematyka ze względu na identyczny koncept użyty w obu utworach $^{13}$, na potrzeby niniejszego wywodu wystarczy jednak, jeśli pominiemy szerszy kontekst i ogólne przesłanie tekstu, skupimy zaś uwagę na ostatnim wersie. Komentarze do Fraszek zbywają ten wers milczeniem, wyjąwszy objaśnienie czasownika kinąć, w edycji Pelca w postaci 'tu: poruszyć, podrzucié' ${ }^{14}$.

Najwyraźniej „dusza” zdaniem wydawców nie wymagała objaśnienia jako wyraz zbyt oczywisty, tymczasem kontekst sytuacyjny wyraźnie się takiej eksplikacji domaga, przy czym nie do końca można się zgodzić z definicjami słowników historycznych. W Słowniku polszczyzny XVI wieku wśród znaczeń leksemu „dusza” znajdujemy następujące: „6. eufem. Pośladki, tyłek”15, opatrzone dwoma cytatami. Jeden z nich to oczywiście ostatni wers Fr I 60 Kochanowskiego, drugi zaś - zupełnie chybiony - to przykład z Krótkiej rozprawy Mikołaja Reja: „Nie zawadzi też koniczek wałaszek inochodniczek, Bo szkoda tej starej dusze, Iż sie na złej szkapie kłusze"16. Szczególnie ów drugi, jakże bałamutny, cytat potwierdza, że znakomite skądinąd opracowanie leksykograficznie nie zauważa istoty sprawy. Tym samym tropem idzie też Słownik polszczyzny Jana Kochanowskiego, dając definicję 'eufemizm - pośladki' ${ }^{17}$, opatrzoną odpowiednim cytatem z Fr I 60. Tymczasem w obu słownikach należało dać odsyłacz „dusza zob. dupa”, bo takie właśnie jest rozwiązanie zagadki: czarnoleski poeta użył przestawki fonetycznej

${ }^{12}$ Za zwrócenie uwagi na to miejsce dziękuję prof. Romanowi Mazurkiewiczowi.

${ }^{13}$ Fraszka ta wpisuje się w cały szereg żartobliwych epigramów na temat astrologów czy, szerzej, uczonych. Vide Jerzy Kroczak, „Jeśli mnie wieźdźba prawdziwa uwodzi...” Prognostyki i znaki cudowne w polskiej literaturze barokowej (Wrocław: Atut, 2006), 216.

${ }^{14}$ Jan Kochanowski, Fraszki, 1991, 29.

${ }^{15}$ Maria Renata Mayenowa, ed., Stownik polszczyzny XVI wieku, vol. 6 (Wrocław: Ossolineum, 1972), 204.

${ }^{16}$ Ibidem. Oryginalny cytat (transliterowany) tutaj został zamieniony na transkrypcję.

${ }^{17}$ Marian Kucała, ed., Stownik polszczyzny Jana Kochanowskiego, vol. 1 (Kraków: IJP PAN, 1994), 443. 
i zamiast wulgarnego „dupą kinie” użył żartobliwego wyrażenia-przyzwoitki „duszą kinie”. Nie pierwszy to raz ucieka Kochanowski w gry słów, żeby uniknąć wyrazu wulgarnego - cytowane powyżej „nieznajomym nie daj dupia” z Fr I 37 należy przecież do tej samej kategorii uników.

We właściwym rozumieniu użytej przez Kochanowskiego przestawki fonetycznej upewnia nas jednak przede wszystkim fakt, że podobne podmianki, motywowane już to względami obyczajowymi, już to stanowiące po prostu żart słowny, pojawiały się i w innych polskich tekstach. Najsłynniejszy chyba przykład zidentyfikował Roman Jakobson w obscenicznej pieśni żakowskiej z 1417 roku znanej jako Cantilena inhonesta. Pieśń owa, odkryta w 1892 roku przez Władysława Nehringa w rękopisie ówczesnej wrocławskiej Biblioteki Miejskiej, dzisiejszej Biblioteki Uniwersytetu Wrockawskiego (sygn. I Q 466), jest erotykiem o dość swobodnej treści, posługującym się jednak kunsztowną metaforyką miłosną. Obsceniczne słownictwo w ogóle nie pojawia się w tekście, ale warto uważnie przeczytać ostatnią strofkę, w którym młodzieniec rozczarowany niewiernością swojej wybranki składa jej następującą propozycję:

Mniszli, panno, bych był ślep,

uderzym ja kijem w kierz,

wyżenu zajece ${ }^{18}$.

Otóż w metaforycznym wyrażeniu „uderzym ja kijem w kierz” (czyli 'uderzę kijem w krzak') należy się, zdaniem Jakobsona, doszukać drugiego dna, a mianowicie przestawki fonetycznej, i wers ten czytać „uderzym ja pyjem w kiep” ${ }^{19}$. Mielibyśmy więc do czynienia z przykryciem wulgarnych określeń oznaczających genitalia męskie („,pyje”) i kobiece („kiep”), a całą frazę należałoby rozumieć już nie metaforycznie, lecz bardzo dosłownie - jako niewybredny opis spółkowania.

Fonetyczne podmianki spotykamy także później, czego przykładem określenie „murwa”, będące zamiennikiem leksemu „kurwa”. Podmiankę ową spotykamy zarówno w XVII-wiecznych zapiskach sądowych z Wilna, gdzie pojawia się jako obelga $^{20}$, jak i w znanym zbiorze przysłów autorstwa Salomona Rysińskiego ${ }^{21}$,

${ }^{18}$ Maciej Eder et Wacław Twardzik, „Czy staropolska kicz/kić naprawdę była wyrazem nieprzyzwoitym? («Cantilena inhonesta» odczytana na nowo)", in Od fonemu do tekstu. Prace dedykowane Profesorowi Romanowi Laskowskiemu, ed. Ireneusz Bobrowski et Krystyna Kowalik (Kraków: Lexis, 2006), 172.

${ }^{19}$ Roman Jakobson, „Slezsko-polská cantilena inhonesta ze začátku XV. stoletî”, Národopisný Věstník Českoslovanský 27-28, no. 1-2 (1935-1934): 83.

${ }^{20}$ David Frick, „«Słowa uszczypliwe», «słowa nieuczciwe». Język sporów sądowych i ruska polemika”, Terminus 12, no. 2 (2010): 22; David Frick, „«Pochwałki na zdrowie, słowa uszczypliwe, złe a zapamiętałe przedsięwzięte umysły». Obelgi starowileńskie ad honorem Durani”, in Amoenitates vel lepores philologiae, ed. Roman Laskowski et Roman Mazurkiewicz (Kraków: IJP PAN, 2007), 101.

${ }^{21}$ Salomon Rysiński, Przypowieści polskie... zebrane, a teraz nowo wydane i na wielu miejscach poprawione (Kraków: Stanisław Giermański, 1634). 
m.in. „Póty murwa miłuje, póki w mieszku czuje” (k. G2r), „Złodziej mi nie brat, murwa mi nie siostra” (k. J3r), „Ożenił sie kołodziej, pojął murwę sam złodziej” (k. G1r). Z kolei Grzegorz Knapiusz, inny zbieracz przysłów a zarazem pionier polskiej leksykografii, używał w swoim dziele pt. Thesaurus Polono-Latino-Graecus (1621) przeróżnych słów-przyzwoitek, by chronić co wrażliwsze uszy swoich czytelników. Przy haśle „Mowa mięszana” dał nawet teoretyczne uzasadnienie takich zabiegów, pisząc, że można się uciec do barbaryzmu, by w ten sposób uciec od wyrazu obscenicznego („Tertia causa inserendi peregrina est honestas et fuga obscoenitatis" $)^{22}$. Nie ma zatem powodu, by w podobnych zabiegach Kochanowskiego nie widzieć celowej gry, mającej na celu wydobycie sensów erotycznych przez ich rzekome przykrycie przyzwoitką; zapewne nie bez intencji ironicznych.

2.

Omawiane powyżej cytaty z Fr I 37 i I 60 pokazują, że użyte implicite przez Kochanowskiego, pod postacią zagadki, określenie „dawać dupy” funkcjonuje w kontekście erotycznym (obscenicznym), a nie skatologicznym. Widać tu dość wyraźnie, że nazwa części pośledniej bywa przenoszona wprost na kobiece genitalia. Trudno przypuścić, by to przeniesienie było zaskakujące, skoro poświadczeń znaleźć można sporo zarówno we współczesnej kulturze popularnej, jak i w folklorze. Zacytujmy przyśpiewkę podkrakowską z połowy XX wieku, w której młoda dziewczyna cieszy się z widocznych symptomów dojrzewania, oraz drugą, zapisaną przez Kolberga pod koniec XIX wieku na Mazurach, w której pada niedwuznaczna propozycja seksualna:

Ciese jo sie, ciese,

ze mi cycki rosno,

dupa mi sie piórcy,

bede dawać wiosną ${ }^{23}$.

A ja, mularz, kominy muruje,

która dziewka krzywa w dupie,

to ją naprostuję ${ }^{24}$.

Obie te przyśpiewki jasno pokazują, że leksem „dupa” funkcjonuje w znaczeniu seksualnym. Przykłady zebrane z innych źródeł, współczesnych Kochanowskiemu i wcześniejszych, sugerują z kolei, że różnica między culus oraz cunus

${ }^{22}$ Maciej Eder, „O słownikach osobliwych, czyli przyczynek do sarmackiej leksykografii”, in Amoenitates vel lepores philologiae, ed. Roman Laskowski et Roman Mazurkiewicz (Kraków: IJP PAN, 2007), 84-87.

${ }^{23}$ Dobrosława Wężowicz-Ziółkowska, Miłość ludowa. Wzory miłości wieśniaczej w polskiej pieśni ludowej XVIII-XX wieku (Wrocław: PTL, 1991), 176.

${ }^{24}$ Ibidem, 154. 
zaciera się znacznie częściej i na znacznie głębszym poziomie, niż moglibyśmy na pierwszy rzut oka podejrzewać.

W rękopisie Mikołaja z Lublina z 1447 roku (w zbiorach Biblioteki Jagiellońskiej nr 5230) znajdują się dwa polskie przysłowia; zapis literowy jednego z nich przedstawia się następująco: Tak prawy sowka sobye rzyc lowk ${ }^{25}$. W literaturze przedmiotu tak ów zapis jest transkrybowany: „Tak prawi sowka: sobie rzyć łowka" ${ }^{26}$, co ma oznaczać, zdaniem Krzyżanowskiego, że brzuch umie dbać o siebie, łowić strawę ${ }^{27}$. To wyjaśnienie dałoby się w ostateczności obronić, ale jak uzasadnić, że słowa powyższe padają z ust sowy, nijak niepasującej do reszty przysłowia? Dawszy spokój karkołomnym domysłom, dużo sensowniej w zapisie sowka dopatrzyć się imienia Zofka (notabene ten właśnie fonetyczny wariant imienia Zofia ma bogate poświadczenie w Staropolskim słowniku nazw osobowych ${ }^{28}$ ) i przyjąć transkrypcję: „Tak prawi Zofka: sobie rzyć łowka”. Tym sposobem zostaje przywrócony sens przysłowiu, które odnosi się do erotycznej atrakcyjności niewieściej: oto kobiece wdzięki („rzyć”) okazują się pułapką (,sobiełowką") ${ }^{29}$ czy też sidłem, w które dają się złapać mężczyźni. Innymi słowy, seksapil jest najskuteczniejszą bronią kobiecą. Z całą pewnością „rzyć” nie ma tutaj znaczenia 'zadek, tyłek, odbyt, podex, anus', jak chcieliby autorzy Stownika staropolskiego ${ }^{30}$.

Drugi przykład jest może mniej oczywisty, ale zarazem dobrze pokazuje stopniowe zatarcie znaczeniowe leksemu „rzyć” (czy też synonimicznego „dupa”), który, w zależności od kontekstu, może się odnosić albo do odbytu, albo do (kobiecych) genitaliów, albo do obu tych miejsc jednocześnie. Oto w jednym z figlików Reja, zatytułowanym Dziewka, co czerwone nogi miała, pewien młodzieniec dostrzega praczkę stojącą boso na lodzie, kolor jej odmrożonych nóg tłumaczy jednak po swojemu: „tu ogień w rzyci srogi”. To spostrzeżenie prowadzi młodzieńca do złożenia chłopce propozycji, „aby mu kiełbaskę upiekła”31. Pewnie nie da się precyzyjnie rozstrzygnąć, co „ogień w rzyci” miałby dokładnie oznaczać (culus czy cunus?), ogólny kontekst seksualny jest jednak wystarczająco czytelny. Widoczne tutaj zamazanie sensów zdaje się potwierdzać ogólna obserwacja Pawła Stępnia, który w zbiorze Reja naliczył 54 epigramaty o treści

${ }^{25}$ Aleksander Brückner, „Polnische Sprichwörter im XV Jahrhundert”, Archiv für Slavische Philologie 15 (1893): 475.

${ }^{26}$ Julian Krzyżanowski, ed., Nowa księga przystów $i$ wyrażeń przystowiowych polskich, vol. 3 (Warszawa: PIW, 1972), 270.

${ }^{27}$ Julian Krzyżanowski, „U średniowiecznych źródeł przysłów polskich”, in Szkice folklorystyczne, vol. 3 (Kraków: Wydawnictwo Literackie, 1980), 183.

${ }^{28}$ Witold Taszycki, ed., Stownik staropolskich nazw osobowych, vol. 6 (Wrocław: Ossolineum, 1981), 330.

${ }^{29}$ Vide Stanisław Urbańczyk, ed., Stownik staropolski, vol. 8 (Wrocław: Ossolineum, 1981), 328.

${ }^{30}$ Ibidem, 8: 107.

${ }^{31}$ Mikołaj Rej, Figliki, ed. Maria Bokszczanin (Warszawa: PIW, 1974), 52. 
skatologicznej, 30 o tematyce seksualnej, „przy czym część tekstów należy do obu tych dwóch grup tematycznych jednocześnie" ${ }^{32}$.

Idźmy dalej. W XV-wiecznej Europie dość sporym zainteresowaniem czytelniczym cieszył się utwór Dialogus Salomonis cum Marcolfo (Dialog Salomona $z$ Marchołtem) składający się w swej zasadniczej części ze sporu słownego między biblijnym królem, utożsamiającym summę ludzkiej wiedzy, oraz nieokrzesanym wieśniakiem, niepozbawionym jednak zdroworozsądkowej mądrości i - przede wszystkim - chłopskiego sprytu. W 1521 roku ukazał się przekład polski tego utworu autorstwa Jana z Koszyczek, zatytułowany Rozmowy, jakie miat król Salomon mądry z Marchołtem grubym a sposnym ${ }^{33}$. Tekst dostarcza niezliczonych przykładów na przemieszanie sacrum i profanum, Biblii i kloaki, obscenów i skatologii. Na potrzeby niniejszego szkicu przywołajmy kilka miejsc, które najmocniej wspierają tezę o niejednoznaczności semantycznej dolnych części ciała.

Gdy Salomon przemawia słowami biblijnymi, niemal dosłownie cytując werset Księgi Przysłów 17, 7: „Rozmaite przyczyny wymyśla, który sie z przyjacielem rozstać chce”, Marchołt mu na to rzecze z prosta: „Niewiasta, która nie chce przyzwolić, mówi, by miała krostawą rzyć" ${ }^{34}$, co jest bardzo wiernym przekładem łacińskiego „Mulier que non vult consentire indicat se scabiosum culum habere" 35 . W innym natomiast miejscu przekład jest mniej dokładny, bo gdy Marchołt polski powiada „Niewiasta ciała tłustego rada dawa żywota swojego" ${ }^{36}$, w oryginale czytamy „Mulier pinguis et grossa est largior in dando iussa” ${ }^{37}$ (tj. „Kobieta gruba i tłusta głośniej pierdzi”). Jest to przypadek wielce interesujący, bo pomieszanie sensów skatologicznych i obscenicznych odbywa się $\mathrm{w}$ dialogu między tekstem oryginalnym i jego przekładem.

Kolejny fragment, który warto przytoczyć, nie zachował się niestety w wersji Jana z Koszyczek (do dziś dochowała się tylko połowa przekładu). Mowa o fragmencie, w którym Salomon, idąc tym razem za Mądrością Syracha, chwali kobiety słowami: „Piękna kobieta jest ozdobą swojego męża”, Marchołt mu zaś na to: „Szyję białą ma jak gołąb, w dupie czarna jest jak kret” 38 . Wulgarna odzywka Marchołta zbudowana jest na zasadzie gry słów „in collo” (w szyi), „in culo” (w odbycie). Nie ma tu oczywiście mowy o spółkowaniu, ale mimo to cytat wydaje się istotny. Dostajemy tu bowiem charakterystyczne zestawienie wysokiego

${ }^{32}$ Paweł Stępień, Śmiech w czasach ostatecznych. Tematyka religijna w Figlikach Mikołaja Reja (Warszawa: Wydział Artes Liberales, 2013), 54.

${ }^{33}$ Maciej Eder, trans., Rozmowy Salomona z Marchottem (Wrocław: Atut, 2014).

${ }^{34}$ Ibidem, 84.

${ }^{35}$ Jan M. Ziolkowski, Salomon and Marcolf (Cambridge, Mass.: Harvard University Press, 2008), 60.

${ }^{36}$ Rozmowy Salomona z Marchottem, 82.

${ }^{37}$ Jan M. Ziolkowski, Salomon and Marcolf, 56.

${ }^{38}$ Rozmowy Salomona z Marcholtem, 52. 
z niskim, pachnącego ze śmierdzącym, potęgi kobiecego piękna z ohydą fizjologii. Zdaje się, że na tej samej opozycji zbudowana jest Fr III 78 Kochanowskiego, a potwierdzenie tej intuicji znajdziemy w kolejnych cytatach.

Wspomniawszy Rozmowy Salomona $z$ Marchołtem, nie sposób zamilczeć o utworze, który tematykę erotyczną i skatologiczną (oraz ich pomieszanie) wyeksploatował w sposób niedościgły. Mowa oczywiście o Gargantui i Pantagruelu Rabelais'go. W kontekście interesujących nas tutaj rozważań szczególnie istotne są dwa miejsca. W ks. II rozdz. XV dzieła znajdujemy opowiastkę, którą miał rzekomo przekazać „Frater de cornibus, libro de Compotationibus mendicantium”. Otóż w czasach, kiedy jeszcze zwierzęta mówiły ludzką mową, lew natknął się na pewną kobietę zbierającą chrust w lesie. Kobieta owa:

[...] widząc zbliżającego się lwa, padła ze strachu na wznak, w taki sposób, iż wiatr odwinął jej suknię, spódnicę i koszulę aż po ramiona. Widząc to lew, tknięty litością, przybiegł, aby zobaczyć, czy nie doznała jakiej szkody, a widząc jej tentego, rzekł: „O, biedna kobiecino, któż cię tak skaleczył?”. Wymawiając te słowa, lew spostrzegł lisa i zaczął nań wołać: „Kumie lisie, [...] patrz, co za ogromna rana od rzyci aż po sam pępek: będzie ze cztery, ba, półszósta piędzi. To cios od siekiery; zdaje mi się, że rana musi być dość stara. Zatem, aby muchy się do niej nie przypytały, wycieraj ją bardzo pilnie, proszę cię o to, zewnątrz i wewnątrz: toć masz ogon długi i piękny po temu [...]". Poczciwy lis wycierał bardzo pilnie, tam i sam, zewnątrz i wewnątrz, zaś szelma stara pierdziała i bździła tymczasem, czyniąc smród jak wszyscy diabli. Biedny lis cierpiał srogie męki, nie wiedział bowiem, w którą stronę się obrócić, aby umknąć fetoru bździn tej staruchy: owo kiedy się tak wykręcał, ujrzał, że z tyłu jest jeszcze inna szczelina, nie tak wielka jak ta, którą od much chronił, i że stamtąd idzie na niego ów tak cuchnący i plugawy wiatr ${ }^{39}$.

Współwystępowanie - czy wręcz wymieszanie - tematyki skatologicznej i seksualnej widać tu aż nadto wyraźnie. W innym miejscu dzieła Rabelais'go (ks. I, rozdz. XXXIX), dostajemy z kolei parodię uczonej dysputy, w której podejmowane są zagadnienia sekretów niewieścich. Wymowa tego fragmentu jako żywo przypomina cytowany powyżej figlik Reja i „ogień w rzyci srogi”, tyle że tym razem tematem dociekań jest „,chłód” kobiecych wdzięków:

- Święty Antoni! - rzekł mnich - [...] kiedy już o tym uradzamy, powiedzcie mi: czemu udka panieńskie są zawsze chłodne?

- Tego problematu - rzekł Gargantua - nie ma ani w Arystotelesie, ani w Aleksandrze Afrodyzyjskim, ani w Plutarchu.

- Oto - rzekł mnich - dla trzech przyczyn, dla których jakieś miejsce w przyrodzony sposób utrzymuje się w chłodzie. Primo, ponieważ ścieka po nim woda. Secundo, ponieważ jest to miejsce cieniste, ciemne i osłonięte, gdzie nigdy słońce nie zagląda. A po trzecie, ponieważ jest nieustannie chłodzone przez wiatry ${ }^{40}$.

${ }^{39}$ Franciszek Rabelais, Gargantua i Pantagruel, trans. Tadeusz Żeleński-Boy, vol. 1 (Warszawa: PIW, 1949), 238-240.

${ }^{40}$ Ibidem, 1: 132. 
Niemal identyczne ujęcie „problematu” kobiecych ud znajdujemy i w rodzimej literaturze, mianowicie w wierszu Na panny Jana Andrzeja Morsztyna (w cyklu Lutnia, nr 137) ${ }^{41}$. Podobieństwo do Rabelais'go jest uderzające; $\mathrm{z}$ cała pewnością zasługuje na prześledzenie możliwych filiacji i ogniw pośrednich ${ }^{42}$. Wersja Morsztyna jest następująca:

\footnotetext{
Na panny

Trzy rzeczy czynią wdzięczne lecie chłody: Gęsty cień i wiatr, i wilgotne wody.

A przecię panny mają ciepłe udy

(Co wie, kto się ich dotknął bez obłudy),

Choć tam przez ciemne płyną rzeki gaje

I choć miech tylny wietrzyku dodaje ${ }^{43}$.
}

Literatura XVI i XVII wieku z pewnością dostarczy więcej przykładów na poparcie tezy o bliskości erotyki i skatologii; na przywołanych powyżej wyimkach można chyba poprzestać. Nie od rzeczy będzie jednak, jak się wydaje, przypomnieć jeszcze jedną paralelę, tym razem pochodzącą z folkloru polskiego. Na obecność bardzo podobnych treści w pieśniach ludowych zwraca uwagę Dobrosława Wężowicz-Ziółkowska. Badaczka twierdzi, że wyróżnia je charakterystyczna refleksja na temat natury człowieczej: „Wśród «filozoficznych» obscenów wyraźnie dają się wyodrębnić zwłaszcza teksty, którym można przydać miano refleksji anatomicznych. Podejmują one nieodmiennie ten sam problem teleologiczności usytuowania tego, co pociągające, przy tym, co odpychające, pięknego przy brzydkim. Owo połączenie traktują one jako niezrozumiałą zagadkę natury, jej niepojęty zamysł" ${ }^{44}$. Zacytujmy za autorką fragment pieśni zapisanej przez Kolberga na Mazowszu ok. 1865 roku:

$\mathrm{Oj}$, pisiu moja, pisiu,

oj, cóżeś ty zrobiła,

oj, coś se w kiepskim miejscu

mieszkać polubiła.

Oj, żebyś ty była

na brzuchu, na brodzie,

aleś ty przy dupie,

przy największym smrodzie ${ }^{45}$.

${ }^{41}$ Za zwrócenie uwagi na ten kontekst dziękuję prof. Pawłowi Stępniowi.

${ }^{42}$ Cf. Pseudo-Albert Wielki, O sekretach białogłowskich, ed. Jerzy Kroczak et Joanna Zagożdżon (Wrocław: Atut, 2012), 59.

${ }^{43}$ Jan Andrzej Morsztyn, Utwory zebrane, ed. Leszek Kukulski (Warszawa: PIW, 1971), 90.

${ }^{44}$ Dobrosława Wężowicz-Ziółkowska, Miłość ludowa. Wzory miłości wieśniaczej w polskiej pieśni ludowej XVIII-XX wieku, 181.

${ }^{45}$ Ibidem. 
Druga pieśń pochodzi również z materiałów Kolbergowskich. Wybitny etnograf zapisał ją ok. roku 1850, tym razem w Małopolsce, nigdy jednak nie ogłosił tego tekstu drukiem; wraz ze sporą liczbą innych frywolnych utworów trafił do niewydanych teczek rękopiśmiennych (czy dlatego, że tym razem mowa o męskich genitaliach?):

Patulu, patulu - tyś moje kochanie

znalazłeś ty sobie przy d... mieszkanie.

Zeby to przy ręce, albo to przy nodze,

ale to tam kicuś przy największym smrodzie ${ }^{46}$.

Na koniec, tytułem uzupełnienia, cytat pochodzący z nieco dalszego kręgu kulturowego, mianowicie z XVII-wiecznej Anglii. Jednym z najbardziej zdumiewających dokumentów życia we wczesnonowożytnym Londynie jest dziennik pisany przez Samuela Pepysa w latach 1660-1669. Autor pisał diariusz wyłącznie dla siebie, posługiwał się przy tym skomplikowanym szyfrem, mógł więc sobie pozwalać na całkowitą szczerość - i tak też czynił. Intymne relacje z żoną są zaledwie jednym $z$ wielu tematów, które mogą wywołać niezdrowe zaciekawienie współczesnego czytelnika. Otóż pod datą 5 sierpnia 1660 znajdujemy wpis: „Żona w okrutnych bolach z przyczyny wrzodów na..., na co cierpiała w pierwszych leciech naszego małżeństwa" ${ }^{47}$, a później w kolejnych miesiącach, obserwujemy narastająca frustrację Pepysa nie tyle z troski o stan zdrowia żony, ile z powodu przymusowej abstynencji seksualnej. (Przekład polski jest zresztą nieco bałamutny, w oryginale bowiem zapiska pojawia się pod datą 2 sierpnia, a 5 sierpnia Pepys tylko czyni aluzję do choroby żony $)^{48}$.

3.

Celem powyższej antologii cytatów było pokazanie, że treści skatologiczne i obsceniczne wcale nie muszą się wykluczać, a granica między oboma sferami cielesnymi bywa bardzo rozmyta. Rzecz jasna, zaproponowane powyżej rozumienie Fr III 87 ma sens o tyle, o ile zgodzimy się, że „Źwierze o jednym oku”, na które „Ślepym bełtem [...] ugadzają”, to rzeczywiście obraz kobiecych genitaliów, być może nie całkiem precyzyjnie odróżnianych od części pośledniej. Dla wzmocnienia przyjętej linii interpretacyjnej warto więc wskazać kilka dalszych tropów - choćby i zalążkowych - w nadziei, że okażą się one warte pogłębienia i rozwinięcia w dalszych studiach.

Po pierwsze, ,źwierzę [...], które zawżdy stoi w kroku” byłoby wprawdzie na tle obscenów u Kochanowskiego i na tle samych Fraszek metaforą dość niecodzienną,

${ }^{46}$ Ibidem.

${ }^{47}$ Samuel Pepys, Dziennik, trans. Maria Dąbrowska, vol. 1 (Warszawa: PIW, 1966), 89.

${ }^{48}$ Samuel Pepys, „The Diary of Samuel Pepys: Daily entries from the 17th century London diary”, 2012, http://www.pepysdiary.com/diary/1660/08/02/ (acc. 5.05.2017). 
metafora jednak intuicyjnie uchwytną. Z całą pewnością eksploracja szerszych kontekstów literackich odsłoniłaby wiele miejsc, w których kobiece genitalia nazywane są „zwierzęciem”, tutaj ograniczmy się do jednego cytatu z Prób Michela de Montaigne, który w poniższym fragmencie (III 102) idzie niemal dosłownie za Platonem (Timajos 91b-c):

Tak samo u kobiet, członek ich, jakoby łapczywe i łakome zwierzę, gdy mu się w swej porze odmawia pożywienia, szaleje zniecierpliwiony zwłoką; i, napełniając tchem swej wściekłości całe ciało, tamuje przewody, wstrzymuje oddech, sprowadzając tysięczne pragnienia: dopóki, wessawszy w siebie owoc powszechnego pragnienia, nie podleje obficie i nie napoi nasieniem macicy ${ }^{49}$.

Po drugie, „Źwierzę o jednym oku” zwraca uwagę swoim pojedynczym, cyklopim ślepiem. Oko w literaturze antycznej i renesansowej jest nabrzmiałe znaczeniami. Pojawia się przede wszystkim w kontekstach platońskich i neoplatoń$\mathrm{skich}^{50}$, często w związku ze słońcem i kultem solarnym (Heliosem, Apollinem), np. przez Owidiusza słońce nazywane jest „okiem świata” („mundi oculus”), w Sielankach Szymonowica natomiast „okiem dnia pięknego” i gwarantem kosmicznej harmonii ${ }^{51}$. Oko przez Kochanowskiego umieszczone „w kroku” warte jest więc być może namysłu jako, na przykład, zamierzona prowokacja estetyczna. Biorąc pod uwagę fakt, że zadek jest archetypiczną odwrotnością twarzy ${ }^{52}$ - jej zaprzeczeniem, ale i krzywym zwierciadłem - oko stojące „w kroku” również może mieć głębszy i nie do końca rozpoznany sens. Na możliwy kontekst interpretacyjny naprowadza cytowany powyżej Dialog Salomona z Marchołtem, a szczególnie jeden z końcowych rozdziałów utworu. Mianowicie po wielokrotnym ośmieszeniu Salomona przez prostackiego chłopa następuje moment, w którym cierpliwość króla się kończy. Rozsierdzony Salomon wyrzuca więc Marchołta z pałacu, dodając, że nie chce go więcej widzieć na oczy. Wtedy Marchołt, ukrywszy się w przydrożnym piecu, spuszcza spodnie i wystawia „rzyć i jajca” (jak czytamy w przekładzie Jana z Koszyczek), zgorszonemu zaś Salomonowi proponuje, by zajrzał mu „między pośladki” (,in medio culo”), skoro nie chce mu patrzeć „między oczy” (,in medio oculis”) ${ }^{53}$. Użyta w tekście gra słów oculus - culus (oko - zadek) być może nie pozostaje bez związku z obsceniczno-skatologicznym „okiem” u Kochanowskiego.

${ }^{49}$ Michel de Montaigne, Próby, trans. Tadeusz Żeleński-Boy (Kraków: Zielona Sowa, 2004), 649.

${ }^{50}$ Maciej Eder et Marta Wojtkowska-Maksymik, „Platońskie i neoplatońskie konteksty humanitas w literaturze polskiej XVI-XVIII wieku”, in Humanitas. Projekty antropologii humanistycznej, ed. Alina Nowicka-Jeżowa, vol. 2 (Warszawa: Neriton, 2010), 139-141.

${ }^{51}$ Paweł Stępień, „«Na niebie wszystkie rzeczy dobrze są zrządzone» - harmonia wszechświata a mikrokosmos folwarku. O «Żeńcach» Szymona Szymonowica i ich związku z myślą neoplatońską", in Inspiracje neoplatońskie literatury staropolskiej, ed. Alina Nowicka-Jeżowa et Paweł Stępień (Warszawa: Uniwersytet Warszawski, 2000), 163-202.

${ }^{52}$ Zbigniew Libera, Rzyć, aby żyć. Rzecz antropologiczna $w$ trzech aktach z prologiem i epilogiem (Tarnów: Liber Novum, 1995).

${ }^{53}$ Rozmowy Salomona z Marchottem, 74, 116. 
Trzeci trop dotyczy fragmentu ,ślepym bełtem w nie [scil. źwierzę] strzelają a na oko ugadzają". Jednoznacznie seksualnych sensów oczywiście nie sposób się tu dopatrzyć, ale użyta w tekście metaforyka takie rozumienie bezsprzecznie uzasadnia. Więcej nawet, w innych miejscach Fraszek natrafiamy na podobieństwa leksykalne z Fr III 78, które hipotezę seksualną znacząco wzmacniają. Czasownik ugodzić/ugadzać występuje we Fraszkach czterokrotnie: obok Fr III 78 pojawia się w Fr II 94 O miłości (człowieka może ugodzić strzała miłości), w Fr III 65 Małemu wielkiej nadzieje Radziwiłłowi (bohater fraszki, gdy dorośnie, będzie umiał ugodzić w pierścień „gładką kopiją”) i w najbardziej nas tutaj interesującej Fr III 86 O flisie. Fraszka opowiada o karczmarzu i jego żonie: oto w ich zajeździe pojawia się flis, który wprawdzie chce odpocząć po trudach podróży, ale zarazem pragnie uwieść żonę gospodarza. Zazdrosny karczmarz próbuje pilnować żony, lecz z nastaniem późnej pory ogarnia go coraz większe zmęczenie. Wreszcie zakrywa ręką „cisa” żony i zapada w sen, tymczasem flis mimo przeszkadzającej ręki spełnia cielesny uczynek z gospodynią:

Kiedy gospodarz nie mógł już przesiedziéć flisá,

Nie tu, pry, łgáć - wzniózwszy gzłá, nákrył dłonią cisá.

Usnął, ściány się wspárwszy. Flis ku pániéj godzi,

Onéj téż nie od tego - ręká tylko szkodzi.

„Namniejsza to - rzecze flis - tákże miedzy spáry”,

W grosz ugodził, dobywszy krzoski z száráwáry.

Fraszka powyższa zamyka cały zbiór, a interesujący nas wers końcowy jest, ipso facto, ostatnim wersem Fraszek. Spółkowanie zostało tu oddane czasownikiem ugodzić, a więc dokładnie tym samym, którym Kochanowski posługuje się w Fr III 78. Ta zbieżność, mimo że wymaga weryfikacji na szerszym materiale leksykograficznym, zdaje się uprawdopodobniać hipotezę, że „ślepy bełt” celujący w „oko” należy jednak do metaforyki seksualnej.

Czwarty wreszcie wątek warty podjęcia w dalszych studiach dotyczy ponownie „oka” i ,ślepego bełtu”, ale tym razem postrzeganych w nieco innej perspektywie. Trudno oczywiście o jednoznaczne rozstrzygnięcia, bo w korpusie Kochanowskiego brak dostatecznego materiału porównawczego, wydaje się jednak, że Słownik polszczyzny Jana Kochanowskiego, definiując ślepy jako 'okragło zakończony ${ }^{54}$, zbyt mocno trzyma się znaczenia, które podpowiada ów (jednostkowy) kontekst Fr III 78. Warto bowiem zauważyć, że przymiotnik „ślepy” został użyty przez Kochanowskiego w bezpośredniej bliskości rzeczownika „oko” i być może w tym zestawieniu należy się dopatrywać klucza interpretacyjnego. Zauważmy przy tym, że to nie „oko” jest ślepe - jak podpowiadałaby utarta frazeologia, lecz „bełt”. Jakkolwiek rzecz się ma, mielibyśmy tutaj znamienne odwrócenie,

${ }^{54}$ Marian Kucała, ed., Stownik polszczyzny Jana Kochanowskiego, vol. 4 (Kraków: IJP PAN, 2008), 722 . 
bo mierzenie do celu wymaga znakomitego wzroku (bystrego oka), a tutaj do strzału składa się przedmiot „ślepy” (tj. bełt), a celem jest widzące „oko”. Może to skontrastowanie sensów jest przypadkowe, a może zamierzone. Warto by chyba i ten trop podjąć dla pełniejszego zrozumienia Fr III 78 oraz, siłą rzeczy, całego zbioru fraszek.

4.

Czytelnik osądzi, czy przedstawione powyżej argumenty są wystarczające, by we fraszce III 78 widzieć zagadkę o podtekście erotyczno-skatologicznym. Nie byłaby to rzecz nowa: sam zbiór Kochanowskiego dostarcza wielu przykładów na to, że taka tematyka nie była poecie obca. Nawet jeśli Januszowski próbował dokonywać na Fraszkach cenzorskich zabiegów, w ostatecznej wersji zbioru - tej, którą znamy z wydania 1584 - dowodów na obscena i skatologię jest dostatecznie dużo, by taką tezę obronić. Zupełnie osobnym problemem jest to, że treści nieprzystojne bądź wulgarne były przez poetów renesansowych traktowane na równi z tematyką podniosłą: wiemy przecież, że Kochanowski musiał bronić niektórych własnych fraszek przed swoim wydawcą. Dziś nie mamy chyba dostatecznej wiedzy o motywacjach stojących za takimi wyborami autorskimi, wypada jednak mieć nadzieję, że niniejszy szkic w jakimś stopniu przyczyni się do zrozumienia, dlaczego dawni poeci aż tak wielką wagę przywiązywali do tematyki niskiej.

\section{MYSTERIOUS “ONE-EYED ANIMAL” OR ON TRIFLE III 78 BY KOCHANOWSKI}

\section{Sum mary}

The paper discusses one of the epigrams by Jan Kochanowski, published in his collection of epigrams called Fraszki (Trifles). The epigram in question, entitled $A$ Riddle (Gadka), was subject to several interpretations exploiting either obscene or scatological readings. The present study aims to show that these two allegedly discrete body-centric perspectives might overlap, since they tend to coincide quite often in the context of European literature of the $16^{\text {th }}$ and $17^{\text {th }}$ centuries. 